\title{
Practices for Identifying, Supporting and Developing Mathematical Giftedness in School Children: The Scene of Hungary (short version)
}

Katalin Fried (ELTE, Budapest, Hungary) and Csaba Szabó (ELTE, Budapest, Hungary) on behalf of the EMS Committee of Education*

An extended version of this paper is published on the Committee's website http://euro-math-soc.eu/sites/default/ files/giftedness-long-HUN.pdf.

\section{Traditions}

The traditions of modern Hungarian mathematics education go back to the 19th century. Around that time several scientific forums were founded: in 1781 a society called the Hungarian Scientific Society, in 1824 the Science Popularising Society (which still exists) and in 1825 The Hungarian Academy of Sciences.

The predecessor of the Bolyai Mathematical Society was founded in 1891 under the name Mathematical and Physical Society. By the end of the 19th century several well-known mathematicians took part in public education, like Rátz László, the teacher of Neumann János (known as John von Neumann) and Wigner Jenó (known as EugeneWigner) or Beke Manó, and Mikola Sándor. In addition, in 1893 Arany Dániel founded the Mathematical Journal for Secondary School Students (age 14-18), $K \ddot{o} M a L$ for short, including a problem solving contest. Many of our famous mathematicians can think of this journal as the start of their careers. Just to mention a few of them Fejér Lipót; Erdós Pál; Szele Tibor; Surányi János; Révész Pál; Szegó Gábor; Hajós György; Hódi Endre; Fuchs László; Császár Ákos; Károlyházy Frigyes.

In 1894 the Hungarian Mathematical and Physical Society initiated a competition for the age group of 18 , the first in the world. Its problems were published worldwide in the so-called Hungarian problem book. Apart from a few months during the war years, $K \ddot{O} M a l$ has been published ever since.

As the result of the rise in mathematical education a new generation of young and talented mathematicians emerged, for whom new competitions needed to be organised. In 1923 a new competition was initiated, and is still organised today every year for the age group 16-18. Mathematicians like Szekeres György; Klein Eszter; Grünwald Géza; Svéd György; Wachsberger Márta; Erdôs Pál; Turán Pál; Gallai Tibor etc. were part of this new generation.

* http://euro-math-soc.eu/sites/default/files/giftedness-shortHUN.pdf
After WWII, in the Socialist era, it was considered to be important to promote the children of the industrial and agricultural workers in order to find more talented children. The school system was subdivided into an 8-year primary school and a 4-year secondary school education. Mass education, however, required a more sophisticated policy and curriculum. In the 1950s a new textbook was written for Year 9 schoolchildren by Péter Rózsa and Gallai Tibor, both excellent theoretical mathematicians. In 1962 a special type of mathematics programme started for grades 9-12. Mass education also required new didactic strategies. According to the ideas of Varga Tamás, if you do not start teaching mathematics from the very beginning, you might have problems later when you want to teach more abstract thoughts. In 1978 the reform was introduced in all schools in Hungary.

\section{Education}

In Hungarian schools, the minimum number of lessons in mathematics in a class is 3 lessons per week, and the maximum is 10. In today's school system in Hungary it is possible to change the status of a child every 2-4 years, however, this does not happen very frequently in sparsely populated areas. All children in Years 1 to 4 learn approximately the same content. In Years 11 and 12 pupils have to specialise in taking more or fewer lessons in mathematics and it is very rare that pupils change class or school.

At the beginning of the 1960s teacher training was separated from theoretical and applied mathematician education at university level. The training for prospective teachers for Years 1 to 4 and Years 9 to 12 had almost had the same structure for the previous one hundred years. The training of prospective teachers for Years 5 to $8 \mathrm{had}$ always been in a contradictory position. Today, education of prospective teachers is split into two significantly different trainings to fit the needs of these levels of education: teachers for children in Years 1 to 4 are prepared for teaching all subjects on a basic level with a didactic and psychological background; teachers for Years 5 to 12 specialise in teaching two subjects and are taught their subjects to a high level with the required didactic background. Their education includes, among others, a course called 'Elementary Mathematics' for 6 semesters, which 
aims at developing their problem-solving skills; and a course called 'Teaching Mathematics' for 4 semesters which discusses how to teach certain mathematical topics or manage talented pupils.

\section{Competitions and off-school programmes}

Apart from education at school, many children take part in after-school activities. In summer some children are invited to such camps according to the results they have achieved at competitions, but for most of the children the camp has to be a playful pastime with a lot of physical activity. There is a huge amount of interest in such camps, so the number of mathematics camps is increasing.

There are numerous competitions in mathematics. Some competitions can be entered directly, that is, without taking part in school, district or county-level competitions, but most competitions have rounds.

- The 'Kürschák József' competition is the most famous competition, organised by the Bolyai Mathematical Society since 1894 , for those students who are about to finish or have finished their secondary school studies within a year.

- The National Competition for Years 11 to 12 is organised by the State of Hungary in all major subjects. The competition in mathematics started in 1923.

- The 'Arany Dániel' competition, organised by the Bolyai Mathematical Society, is for Years 9 to 10. The first such competition was organized in 1947.

- The 'Varga Tamás' competition, organized by MATEGYE on behalf of the Bolyai Mathematical Society, is for Years 7-8. The competition started in 1988.

- The 'Zrínyi Ilona' competition, organised by MATEGYE since 1990, is for Years 2 to 12, with a system of multiple choice questions.

- The 'Kalmár László' competition has been organised by the Science Popularising Society for Years 3 to 8 since 1971.

There are more nationwide competitions but the ones mentioned above are the most popular ones.

At the beginning of the 1970s a new initiative to aid gifted students started. Nowadays, the programme runs under the name of 'The Joy of Thinking' (MaMut (MAtheMatical amUsemenT)) and is organised by those youngsters who took part in these programmes when they were students. They invite the best pupils to their weekend and summer camps to be a part of their famous talent-care programme. Prospective teachers are also invited to observe and learn their teaching methods. It is an honour to take part in the camp, both as a pupil and as a prospective teacher. Back in the the 1970s the Ministry of Education organised a camp for the best students from mathematics competitions as part of their prize. These camps were popular among children and teachers as well.

\section{'BEAR events'}

Lately, a new style of after-school maths activity has come from a group of young people who, as they say, “feel passionate about mathematics education".

Their activities include outdoor maths challenges, maths camps, experience days and treasure hunts. In 2017, about 15,000 people were involved in their programmes.

This wide selection of competitions and the different levels of mathematics education makes it possible for every pupil to achieve their best. In this way, talented pupils are supported within the system. The idea of learning mathematics through problem-solving seems to be very successful. These many competitions and camps make it possible to keep track of the work of the most talented children, keep up their interest and encourage them to develop their skills by preparing for these competitions.

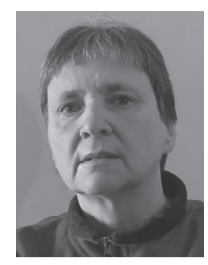

Katalin Fried has been engaged with teacher training at Eötvös Loránd University in Budapest since 1983. She has earned her PhD in mathematics. As an associate professor she is teaching preservice mathematics teachers to several subjects related to mathematical didactics.

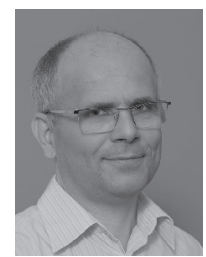

Csaba Szabó is a professor at the Department of Algebra and Number Theory at the Faculty of Sciences of Eötvös Loránd University in Budapest. He has widened his research interest ten years ago from the theory of general algebraic systems to the methodology of teaching mathematics. He is a co-founder and leader of the "Theory and Psychology of Learning Mathematics Research Group" in Hungary. 